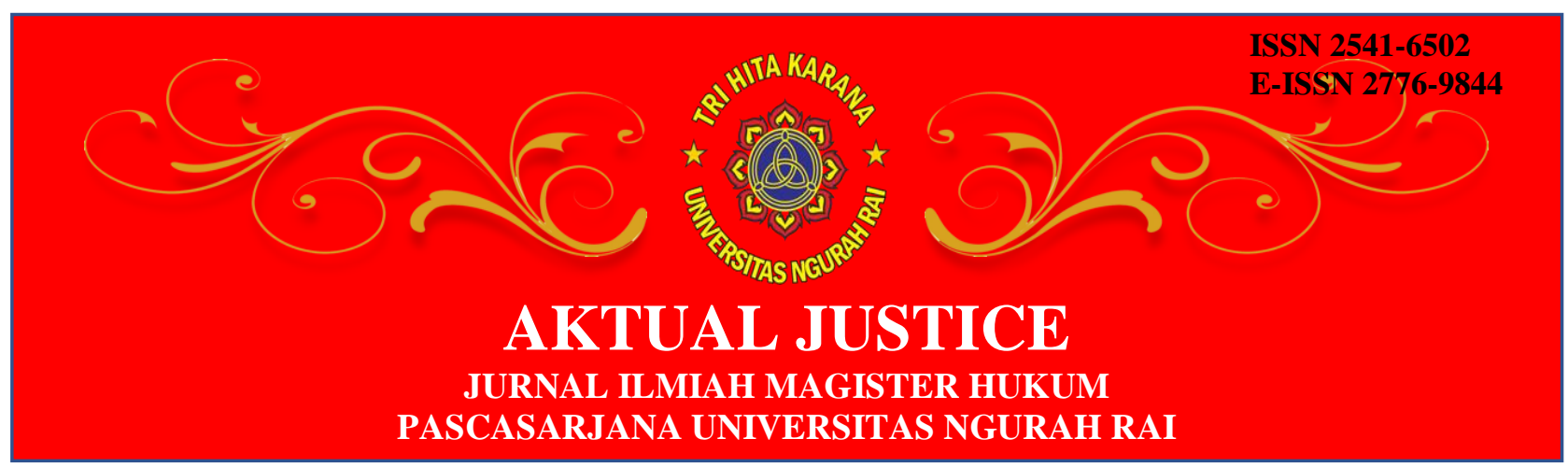

PERLINDUNGAN HUKUM TERHADAP

\title{
KREDITUR ATAS PERJANJIAN KAWIN YANG DIBUAT SETELAH PERKAWINAN
}

\author{
Cokorde Istri Dian Laksmi Dewi \\ Dosen Magister Hukum Universitas Ngurah Rai Denpasar, Email: cokdild@gmail.com
}

\begin{abstract}
This is derived from the Constitutional Court Decision Number 69/PUU-XII/2015, to change is a practice making of a marriage agreement, where before the marriage agreement be made before or when the marriage, as is the Constitutional Court Decision Number 69/PUU-XII/2015 the marriage agreement can be made the marriage agreement at the time of marriage. The changer these norms give a legal impact against to legal events wicht has accurred previously related to third parties of creditors. The problem of legal protection for creditors due to the making of marriage agreement during marriage can be answered for the conducting legal research using the normative juridical legal research method, which refers to formal legal sources. so that the research method can protect creditors from the marriage agreement made during the marriage is with preventive and repressive legal protection, preventive is taking precautions that can be done with the precautionary principle of a creditor before giving credit to the debtor and resolving the problem through legal channels by canceling the marriage agreement or making a civil suit to the district court, as long as the creditor can prove that the marriage agreement was made after an incident occurred. the law with the creditor or the marriage agreement causes a loss to the creditor.
\end{abstract}

Keywords: marriage agreement, property, legal protection for creditor

\begin{abstract}
Abstrak
Setelah dikeluarkannya putusan Mahkamah Konstitusi Nomor 69/PUU-XIII/2015, terjadi perubahan terhadap kebiasaan dalam pembuatan perjanjian perkawinan, dimana sebelumnya perjanjian kawin dibuat sebelum atau pada saat perkawinan, dengan adanya putusan Mahkamah Konstitusi Nomor 69/PUU-XIII/2015 perjanjian kawin dapat dibuat pada saat perkawinan berlangsung. Perubahan norma tersebut memberikan dampak hukum terhadap peristiwa hukum yang telah terjadi sebelumnya terkait dengan pihak ketiga atau kreditur. Permaslahan tentang perlindungan hukum terhadap kreditur akibat pembuatan perjanjian kawin selama perkawinan dapat dijawab dengan melakukan penelitian hukum dengan metode penelitian hukum yuridis normative, yang mengacu pada sumber - sumber hukum formal. Sehingga dengan metode penelitian tersebut untuk dapat melindungi kreditur dalam perjanjian kawin yang dibuat selama perkawinan adalah dengan perlindungan hukum preventif dan represif preventif adalah melakukan pencegahan yang dapat dilakukan dengan prinsip kehati - hatian seorang kreditur
\end{abstract}


sebelum memberikan kredit kepada debitur dan melakukan penyelesaian masalah melalui jalur hukum dengan membatalkan perjanjian kawin maupun melakukan gugatan perdata ke pengadilan negeri, sepanjang kreditur dapat membuktikan bahwa perjanjian kawin tersebut dibuat setelah terjadi peristiwa hukum dengan kreditur atau perjanjian kawin tersebut menimbulkan kerugian kepada kreditur.

Kata Kunci : Perjanjian Kawin, harta, Perlindungan Hukum Kreditur

\section{Pendahuluan}

Pengaruh - pengaruh dan kebiasaan budaya barat yang masuk ke Indonesia dengan berbagai cara mulai diadopsi oleh masyarakat Indonesia, bukan hanya percampuran Bahasa tetapi juga dalam kebiasaan dalam hal perkawinan. Perkawinan merupakan peristiwan hukum terpenting yang dilakukan manusia baik secara prisitual maupun social budaya. Pada masyarakat barat sangat lumrah sebelum menikah pasangan suami istri membuat perjanjian perkawinan terutama terkait dengan harta. Karena seperti telah diketahui sebuah perkawinan bukan hanya tentang bersatunya seorang laki - laki dan perempuan tetapi berakibat pula pada penyatuan hak dan kewajiban termasuk harta benda yang diperoleh selama berkawinan yang disebut dengan harta bersama. Pengaturan mengenai harta benda selama perkawinan dapat dilihat dalam ketentuan pasal 35 undang - undang nomor 1 tahun 1974 ( UU Perkawinan) yang menentukan bahwa :

Ayat (1) : "harta benda yang diperoleh selama perkawinan menjadi harta bersama"

ayat (2) : "harta bawaan dari masing - masing suami dan istri dan harta benda yang diperoleh masing - masing sebagai hadiah atau warisan, adalah di bawah penguasaan masing - masing sepanjang para pihak tidak menentukan hal lain".

Dalam KUHPerdata ketentuan pasal 119 disebutkan bahwa pada hakikatnya perkawinan menyebabkan percampuran dan persatuan harta pasangan menikah kecuali apabila pasangan menikah tersebut membuat 
perjanjian perkawinan yang mengatur mengenai pemisahan harta. ${ }^{1}$ Pembuatan perjanjian perkawinan atau yang biasa disebut dengan Prenuptial Agreement merupakan hal yang populer dilakukan pasangan pasangan muda yang akan menikah. ${ }^{2}$ Pada awalnya perjanjian perkawinan bertentangan dengan nilai - nilai yang ada dalam masyarakat timur, umumnya perjanjian kawin dibuat karena adanya ketimpangan financial antara laki - laki dan perempuan yang akan kawin tersebut misalnya calon istri memiliki usaha dan pekerjaan yang penghasilanya jauh melebihin dari calon suami. Dan, hukum adat di Indonesia tidak mengenal adanya perjanjian kawin karena dianggap kurang pantas dan menyinggung perasaan karena dianggap sebagai persiapan apabila kelak terjadi perceraian. Dalam pola pikiran masyarakat barat yang cenderung bersifat induvidualisme melalui perjanjian kawin akan ada kemandirian dari harta suami dan istri sehingga apabila dikemudian hari salah satu suami atau istri mengalami kebangkrutan maka pihak yang satunya lagi akan mampu menopang kebutuhan rumah tangga sehingga lebih mudah bangkit kembali dari kebangkrutan, selain itu dengan adanya perjanjian kawin dapat mencegah atau setidaknya mengurangi kemungkinan kemungkinan terjadinya sengketa selama perkawinan berlangsung termasuk pada saat terjadinya perceraian, tidak seperti masyarakat Indonesia yang hampir sebagian besar setelah perceraian akan timbul masalah bawaan yaitu terhadap pembagian harta selama perkawinan atau yang kita sebut dengan harta gono - gini. Mengadopsi dari kebiasaan masyarakat barat tersebut dalam undang - undang perkawinan no. 1 tahun 1974 pasal 29 ayat (1) telah diatur bahwa untuk sahnya suatu perjanjian kawin, maka perjanjian kawin tersebut harus didaftarkan pada pegawai

1 Perjanjian Perkawinan; Dasar Hukum, Fungsi, Materi yang Diatur, dan Waktu Pembuatan, http://kcaselawyer.com. Diakses pada hari selasa 26 Januari 2021.

2 Ibid. 
pencatatan perkawinan, atau pada dinas pencatatan pencatatan sipil pada domisili para pihak yang kemudian akan dicatatkan pada buku register yang diperlukan. Namun, sayangnya tidak banyak masyarakat yang tau tentang hal tersebut bahkan ada masyarakat yang melakukan pendaftaran perjanjian kawin di kantor kepaniteraan pengadilan negeri. Umumnya perjanjian kawin dibuat sebelum perkawinan dilangsungkan tetapi karena alasan tertentu tidak menutup kemungkin bagi pasangan suami istri membuat perjanjian kawin saat perkawinan berlangsung, dan pembuatan janji kawin selama perkawinan juga dibolehkan dengan adanya putusan Mahkamah Konstitusi Nomor 69/PUU-XIII/2015, pada amar putusan mengadili, menyatakan pasal 29 ayat (1) undang - undang Nomor 1 tahun 1974 tentang perkawinan (Lembaran Negara Republik Indonesia Tahun 1974 nomor 1, Tambahan Lembaran Negara Indonesia Nomor 3019) bertetangan dengan Undang - Undang Dasar Negera Republik Indonesia tahun 1945 sepanjang tidak dimaknai "pada waktu sebelum dilangsungkan atau selama dalam ikatan perkawinan kedua belah pihak atas persetujuan bersama dapat mengajukan perjanjian tertulis yang disahkan oleh pegawai pencatat perkawinan atau notaris, setelah mana isinya berlaku juga terhadap pihak ketiga sepanjang pihak ketiga tersangkut", 3 dengan adanya putusan dari Mahkamah Konstritusi tersebut perjanjian kawi yang sebelumnya hanya dibuat sebelum perkawinan (prenuptial aggrement) telah bergerser menjadi postnuptial agreement atau dapat dibuat selama perkawinan berlangsung. Dengan munculnya sebuah ketentuan baru akan memberikan dampak pada kehidupan masyarakat, dengan putusan Mahkamah Konstitusi tersebut positifnya adalah dapat memberikan perlindungan terhadap hak - hak konstitusional seseorang yang belum membuat perjanjian kawin

3 Putusan Nomor 69/PUU-XIII/2015 Mahkamah Konstitusi RI, diambil dari https://www.mkri.id/public/content/persidangan/putusan/69_PUU-XIII_2015.pdf. Yang diakses pada hari senin 1 februari 2021. 
tetapi akan memberikan dampak yang negatif apabila perjanjian kawin tersebut dibuat dengan tujuan untuk merugikan orang lain atau pihak ketiga, dimana perjanjian kawin yang dibuat setelah perkawinan berlangsung memberikan peluang kepada suami istri melakukan pemisahan harta bersama selama perkawinan sedangkan harta tersebut sebelumnya telah terikat pada perjanjian kredit.

Dari uraian masalah hukum tersebut diatas dalam penelitian hukum ini perlu untuk dicari pemecahan masalah tentang perlindungan hukum terhadap kreditur apabila perjanjian kawin dibuat setelah dilangsungkan perkawinan dan harta bersama yang dimiliki suami istri selama perkawinan telah dijadikan agunan atau jaminan kredit. Sehingga untuk menjawab permasalahan tersebut maka penelitian ini mengangkat judul tentang "Perlindungan Hukum Teradap Kreditur Atas Perjanjian Kawin Yang Dibuat Setelah Perkawinan".

\section{Metode Penelitian}

Metode penelitian yang dipergunakan dalam penelitian ini adalah metode penelitian yang bersifat yuridis normative, dengan studi keputakaan dimana penelitian yang dilakukan didasarkan kepada ketentuan - ketentuan yang ada dengan mengacu pada teori - teori hukum dari bahan hukum primer khususnya mengacu padal undang - undang perkawian nomor 1 tahun 1974 dan KUHPerdata, serta peraturan peraturan lain yang berkaitan dengan perjanjian perkawinan dan bahan hukum sekunder yakni bahan - bahan yang erat hubungannya dengan bahan hukum primer dan dapat membantu menganalisis dan memahami bahan hukum primer, seperti buku - buku dan diktat - diktat literatur tentang perdata atau perkawinan, hasil - hasil penelitian, hasil seminar, 
hasil karya dari kalangan hukum, serta dokumen - dokumen lain yang berkaitan dengan perjanjian perkawinan. ${ }^{4}$

\section{Hasil dan Pembahasan}

\section{a. Perjanjian Kawin Yang Dibuat Setelah Perkawinan}

Dalam undang - undang keperdataan kita memberikan kebebasan dalam membuat perjanjian, karena pada asasnya membuat perjanjian adalah bebas, maka diatur dalam perjanjian tergantung pada pihak - pihak calon suami - calon istri, asal tidak bertentangan dengan hukum atau undang - undang, agama dan kepatutan atau kesusilaan. ${ }^{5}$ Namun demikian, sampai dengan saat ini belum dibuat regulasi yang mengatur tata cara pembuatan perjanjian kawin dalam masa perkawinan sehingga membuka ruang interpretasi secara luas. ${ }^{6}$

R. Subekti memberikan difinisi tentang perjanjian kawin, Perjanjian kawin adalah suatu perjanjian mengenai harta benda suami istri selama perkawinan mereka yang menyimpang dari asas atau pola yang ditetapkan oleh undang - undang. ${ }^{7}$ Sedangkan Komar Andasasmita mengatakan apa yang dinamakan "perjanjian atau syarat kawin" itu adalah perjanjian yang diadakan oleh bakal atau calon suami - istri dalam mengatur (keadaan) harta benda atau kekayaan sebagai akibat dari perkawinan mereka. ${ }^{8}$ KUHPerdata memberikan beberapa larangan tentang isi perjanjian kawin yaitu :

${ }^{4}$ Marzuki. P.M. (2009). Penelitian Hukum. Jakarta: Kencana. h, 22.

${ }_{5}^{5}$ Prawirohamidjojo. R.S. (1974). Berbagai Masalah Hukum Dalam UU No. 1 Tahun 1974 Tentang Perkawinan. Jakarta : Fakultas Hukum dan Pengetahuan Masyarakat Universitas Trisakti Jakarta. h. 28

${ }^{6}$ Kusuma. C.H. (2018). Kedudukan Hukum Perjanjian Perkawinan Yang Dibuat Setelah Perkawinan Yang dibuat Setelah Perkawinan Terhadap Pihak Ketiga (Pasca Putusan Mahkamah Konstituso Nomor. 69/PUU-XIII/2015). Jurnal Hukum dan Kenotariatan, Vol. 2, jurnal Volume II- Nomor 1 - Februari 2018. h. 176.

${ }^{7}$ Subekti. R. (1994). Pokok - Pokok Hukum Perdata. Jakarta: Intermasa. h. 9.

8 Andasasmita. K. (1990). Notaris II Contoh Akta Otentik dan Penjelasannya, Bandung: Ikatan Notaris Indonesia (INI) Daerah Jawa Barat Cetakan Kedua. h. 53. 
a) Perjanjian tidak boleh bertentangan dengan kesusilaan atau dengan ketertiban umum yang diatur dalam Pasal 139 KUHPerdata.

b) Perjanjian itu tidak boleh menyimpang dari kekuasaan yang oleh KUHPerdata diberikan kepada suami selaku kepala rumah tangga, diatur dalam Pasal 140 ayat (1) KUHPerdata.

c) Suami istri tidak boleh melepaskan hak mereka untuk mewarisi harta peninggalan anak - anak mereka yang diatur dalam Pasal 141 KUHPerdata.

d) Isi perjanjian tersebut tidak boleh menentukan bahwa salah satu pihak akan menanggung hutang lebih besar daripada bagiannya dalam keuntungan, yang diatur dalam Pasal 142 KUHPerdata.

R. Soetojo Prawirohamidjodo, mengatakan bahwa perjanjian kawin adalah suatu perjanjian yang dibuat oleh calon suami istri sebelum atau pada saat perkawinan dilangsungkan untuk mengatur akibat - akibat perkawinan terhadap harta kekayaan mereka. ${ }^{9}$ Bentuk - bentuk perjanjian kawin adalah sebagai berikut :

a. Pisah harta sama sekali (Aigehele uitsluiting van gemeenschap) ${ }^{10}$

Di Indonesia kebanyakan orang kawin dengan kebersamaan harat (tanpa perjanjian kawin) atau apabila dibuat perjanjian kawin meniadakan sama sekali kebersamaan harta sehingga di dalam praktek, perjanjian kawin yang banyak diadakan adalah yang meniadakan sama sekali persatuan harta kekayaan. Menuruut pasal 144 KUHPerdata untuk meniadakan sama sekali persatuan harta kekayaan, yaitu menghendaki agar harta mereka sepanjang perkawinan terpisah sama sekali, maka para pihak di dalam perjanjian kawin harus menyatakan

${ }^{9}$ Ibid, h, 57.

10 Maharani Kartika Puji Karisma, SH. 2011. Akibat hukum Perjanjian Kawin Yang Dibuat Seletah Perkawinan (Studi Kasus : Penetapan Pengadilan Negeri Nomor : 459/Pdt/P/2007/PN.Jkt.TMr). Tesis. Fakultas Hukum Program Magister Kenotariatan Universitas Indonesia. Depok. h, 112. 
bahwa antara mereka calon suami istri itu secara tegas - tegas menyatakan bahwa mereka juga tidak menghendaki adanya persatuan untung dan rugi.

b. Persatuan untung dan rugi (gemenshap van wins ten verlies) ${ }^{11}$

Perkawinan dengan ketentuan persatuan untung dan rugi merupakan penyimpangan terhdap ketentuan undang - undang (pasal 119 KUHPerdata) tentang persatuan bulat harta kekayaan perkawinan. Dalam persatuan untung dan rugi, harta yang dimiliki sebelum dilangsungkannya perkawinan adalah harta private masing - masing suami atau istri yang membawa, demikian pula tentang utang yang ada sebelum perkawinan dilangsungkan juga menjadi hutang private suami istri yang bersangkutan.

c. Perjanjian persatuan dan pendapatan (gemeesnschap van vruchten en inkomsten $)^{12}$

Dalam KUHPerdata peraturan yang mengatur perjanjian kwain dengan kebersamaan atay persatuan penghasilan dan pendapatan hanya ada satu pasal saja yaitu pasal 164, disamping itu terdapat tiga pasal yang mengatur baik tentang persatuan untung dan rugi maupun tentang persatuan hasil dan pendapatan, yaitu pasal 165 sampai dengan pasal 167.

Perjanjian kawin dibuat pada saat atau sebelum dilangsungkan perkawinan dimana kedua belah pihak bersepakat mengadakan perjanjian tertulis yang kemudian disahkan oleh pegawai pencatatan perkawinan. Isi dari perjanjian perkawinan tersebut bersifat mengikat bagi para pihak termasuk pada pihak ketiga yang tersangkut, isi dari perjanjian perkawinan juga berisi tentang konsekuensi dari pemisahan harta apabila terjadi perceraian atau karena kematian. Yang menimbulkan permasalahan saat

11 Ibid.

12 Ibid. 
ini adalah adanya Putusan Mahkamah Konstitusi Nomor 69/PUUXIII/2015 yang memperbolehkan bahwa perjanjian kawin dilakukan kapan saja bahkan selama perkawinan dilangsungkan. Dengan munculnya Putusan Mahkamah Konstitusi tersebut merubah tatanan norma dan pola perjanjian perkawinan yang terdapat dalam Undang - Undang Perkawinan No. 1 tahun 1974, sehingga subtstansinya akan berubah sebagai berikut:

1. Pasal 29 ayat (1) Undang - Undang Nomor 1 Tahun 1974 tentang Perkawinan ( Lembaran Negara Republik Indonesia Tahun 1974 Nomor 1, Tambahan Lembaran Negara Republik Indinesia nomor 3019) bertentangan dengan Undang - Undang Dasar Negara Republik Indonesia Tahun 1945 sepanjang tidak dimaknai “Pada waktu, sebelum dilangsungkan perkawinan kedua belah pihak atas persetujuan bersama dapat mengajukan perjanjian tertulis yang disahkan oleh pegawai pencatat perkawinan atau notaris, setelah mana isinya berlaku juga terhadap pihak ketiga sepanjang pihak ketiga tersangkut";

2. Pasal 29 ayat (2) Undang - Undang Nomor 1 Tahun 1974 tentang Perkawinan ( Lembaran Negara Republik Indonesia Tahun 1974 Nomor 1, Tambahan Lembaran Negara Republik Indinesia nomor 3019) tidak mempunyai kekuatan hukum mengikat sepanjang tidak dimaknai "Pada waktu, sebelum dilangsungkan atau selama dalam ikatan perkawinan kedua belah pihak atas persetujuan bersama dapat mengajukan perjanjian tertulis yang disahkan oleh pegawai pencatat perkawinan atau notaris, setelah mana isinya berlaku juga kepada pihak ketiga sepanjang pihak ketiga tersagkut";

3. Pasal 29 ayat (3) Undang - Undang Nomor 1 Tahun 1974 tentang Perkawinan ( Lembaran Negara Republik Indonesia Tahun 1974 Nomor 1, Tambahan Lembaran Negara Republik Indinesia nomor 3019) bertentangan dengan Undang - Undang Dasar Negara Republik Indonesia Tahun 1945 sepanjang tidak dimaknai "Perjanjian tersebut 
mulai berlaku sejak perkawinan dilangsungkan, kecuali ditentukan lain dalam Perjanjian Perkawinan";

4. Pasal 29 ayat (4) Undang - Undang Nomor 1 Tahun 1974 tentang Perkawinan ( Lembaran Negara Republik Indonesia Tahun 1974 Nomor 1, Tambahan Lembaran Negara Republik Indinesia nomor 3019) tidak mempunyai kekuatan hukum mengikat sepanjang tidak dimaknai “Selama perkawinan berlangsung, perjanjian perkawinan dapat mengenai harta perkawinan atau perjanjian lainnya, tidak dapat diubah atau dicabut, kecuali bila dari kedua belah pihak ada persetujuan untuk mengubah atau mencabut, dan perubahan atau pencabutan itu tidak merugikan pihak ketiga".

Dalam pasal 29 ayat (4) Putusan Mahkamah Konstitusi Nomor 69 tahun 2015, perjanjian kawin mengenai harta atau perjanjian lainnya, meskipun para pihak berhak menentukan isi dari perjanjian yang dibuatnya tetapi isi dari perjanjian tersebut harus memperhatikan terhadap berlakunya perjanjian perkawinan tersebut, apabila di dalam perjanjian kawin yang dibuat setelah perkawinan tersebut menyebutkan bahwa "perjanjian tersebut dinyatakan berlaku sejak saat perkawinan", maka dapat dimaknai bahwa telah terjadi percampuran harta. Dalam situasi seperti itu menjadi sulit untuk melakukan pembagian harta campuran. Sehingga akan lebih baik apabila sejak saat perkawinan hingga tanggal perjanjian kawin ini dibuat harta yang telah ada tetap dianggap sebagai harta campuran, sedangkan sejak perjanjian kawin ini dibuat dan ditandatangani untuk selanjutnya harta yang diperoleh menjadi terpisah seperti apa yang disepakati oleh para pihak dalam perjanjian tersebut. Beberapa hal yang perlu untuk diperhatikan dengan adanya perjanjian kawin setelah perkawinan adalah :

1. Dalam perjanjian tersebut tidak dapat diperjanjikan bahwa salah satu pihak akan menanggung hutang yang lebih banyak atau 
lebih besar daripada bagiannya dalam persatuan keuntungan. Pilato berpendapat sebagaimana dikutip oleh Prawirohamidjojo dan Asis Safiedien dalam bukunya : bahwa janji yang demikian harus dianggap tidak ada karena bertentangan dengan undang undang. Dengan demikian suami istri masing - masing menanggung setengah bagian dari hutang maupun keuntungan. ${ }^{13}$

2. Pasangan suami dan istri yang melakukan perjanjian kawin selama perkawinan sebaiknya membuat daftar harta yang telah dimiliki sebelum perjanjian tersebut dibuat dan dicatatkan karena harta tersebut tidak menjadi bagian dari pisah harta, sehingga kemudian apabila terjadi percerain maka status harta sebelum perjanjian perkawinan itu dibuat menjadi harta bersama atau harta gono gini.

3. Apabila dikemudian hari diketahui bahwa sebelum dibuat perjanjian kawin terdapat tambahan harta diluar sepengetahuan salah satu pihak yang kemudian akan menimbulkan perselisihan diantara para pihak maka akan dianggap sebagai harta bersama sepanjang dapat dibuktikan harta tersebut didapat selama perkawinan dan sebelum dibuatnya perjanjian kawin yang dibuat selama perkawinan, dan apabila harta tersebut terikat pada pihak ketiga maka akibat yang ditimbulkan tidak boleh merugikan pihak ketiga atau kreditur.

4. Dalam perjanjian kawin dimungkinkan untuk mencantumkan klausula tentang syarat menangguhkan, syarat membatalkan dan tenggang waktu.

13 Prawirohamidjojo. S. dan Safiodien. A. (1987). Hukum Orang dan Keluarga. Bandung : Alumni. Cetakan V. h. 80. 
a. Syarat menangguhkan bergantung pada peristiwa yang akan terjadi dikemudian hari dan belum tentu akan terjadi dimana perikatan tersebut tidak akan terjadi apabila peristiwa yang dimaksud tidak terjadi.

b. Syarat batal adalah mengenai perikatan dapat batal pabila para pihak menghendakinya atau disyaratkan akibat - akibat yang dapat menyebabkan batalnya perjanjian kawin tersebut, sehingga semua akan kembalin lagi seperti semula sebelum adanya perjanjian kawin, seolah - olah tidak pernah ada suatu perikatan sebelumnya sebagaimana yang dimaksud dalam Pasal 1253 KUHperdata.

c. Syarat tenggang waktu, dengan menetapkan tenggang waktu dalam perjanjian tidak menangguhkan perikatan hanya saja menangguhkan pelaksanaan dan memberi kepastian pada pihak ketiga akan dilakukan pada waktu yang telah diperjanjikan, ketentuan tersebut dapat dilihat pada ketentuan pasal 1268 KUHPerdata.

5. Dalam perjanjian kawin tidak dapat memasukkan atau menetapkan bahwa tunduk atau berlakunya perundang undangan asing sebagai pilihan hukumnya.

6. Perjanjian kawin yang dibuat selama perkawinan berlangsung dibuat oleh notaris dengan kemudian diminta penetapan dari pengadilan.

7. Harta bersama yang sebelum dibuatnya perjanjian kawin yang telah menjadi objek jaminan kredit harus dikecualikan dalam perjanjian ini, dalam artian harus tetap menjadi bagian harta bersama yang tidak dapat beralih atau berubah status, dimana hal ini dimaksudkan untuk memberikan perlindungan kepada kreditur atau pihak ketiga yang terkait dengan harta tersebut. 
Menindaklanjuti Putusan Mahkamah Konstitusi RI Nomor 69/PUUXIII/2015, Direktorat Jendral Kependudukan dan Pencatatan Sipil mengeluarkan Surat Edaran tanggal 19 Mei 2017 Nomor: 472.2/5876/Dukcapil, perihal pencatatan Pelaporan Perjanjian Perkawinan yang pada pokoknya mengatur bahwa Perjanjian perkawinan dapat dibuat sebelum, pada saat dan selama perkawinan berlangsung dengan akta notaris dan dilaporkan kepada instansi pelaksana teknis atau unit pelaksanaan teknis (UPT) instansi pelaksana. Mengenai teknis pelaksanaanya telah diatur dalam Surat Edaran tersebut untuk dilaksanakan.

\section{b. Perlindungan Hukum Terhadap Kreditur Atas Perjanjian Kawin Yang Dibuat Setelah Perkawinan}

Dengan adanya perjanjian kawin antara suami istri yang dibuat selama perkawinan dan dengan Putusan Mahkamah Konstitusi RI Nomor 69/PUU-XIII/2015 akan menimbulkan akibat hukum dan mengikat bagi para pihak yang mengikatkan diri pada perjanjian tersebut termasuk pula pada pihak ketiga yang memiliki kepentingan dengan harta yang sebelumnya merupakan harta bersama dan kemudian terjadi pemisahan harta dalam bentuk perjanjian kawin. Pihak ketiga atau kreditur dalam memberikan kredit kepada para pihak baik suami maupun istri harus memastikan kedudukan dari harta yang dijadikan agunan tersebut, selain itu debitur juga harus beritikad baik dengan bersikap jujur kepada krediturnya.Dalam kaitanya dengan perlindungan hukum kepada kreditur, maka dapat dilakukan dengan dua cara yaitu :

1. Perlindungan Hukum Preventif

Secara preventif perlindungan hukum yang dapat diberikan kepada kreditur adalah kembali dengan sikap kehati - hatian dari kreditur dalam memperhatikan keabsahan dari perjanjian 
kawin dan bentuk perjanjian kawin yang dibuat terutama terhadap status harta kekayaan dari debitur tersebut. Keabsahan dari perjanjian kawin dapat dilihat dari unsur - unsur perjanjian kawin :

a. Dibuat oleh (calon) suami dan (calon) istri.

b. Dibuat secara tertulis dalam bentuk akta otentik.

c. Tidak melanggar unsur kesusilaan dan ketertiban umum.

d. Unsur tidak boleh dirubah namun dapat dirubah atau dibatalkan selama tidak merugikan pihak ketiga.

2. Perlindungan Hukum Represif

Hal yang menjadi kekhawatiran pada kreditur adalah terkait pada poin (d) dimana apabila debitur tidak beritikad baik dengan menginformasilkan kepada kreditur tentang adanya perubahan maupun pembatalan terhadap perjanjian kawin yang sebelumnya dijadikan acuan dalam pemberian kredit oleh kreditur. Kekhawatiran kreditur tersebut dapat dihindari karena dalam ketentuan Putusan Mahkamah Konstitusi RI Nomor 69/PUU-XIII/2015 apabila kreditur dirugikan dengan adanya pertubahan perjanjian kawin sebagaimana dimaksud diatas maka kreditur harus membuktikan bahwa akibat dari perubahan perjanjian kawin tersebut menimbulkan kerugian pada dirinya dan untuk itu kreditur dapat melakukan gugatan ke pengadilan untuk membatalkan perjanjian kawin yang merugikan kedudukanya sebagai kreditur.

Kerugian pada kreditur akan terjadi apabila debitur bermasalah atau melakukan wanprestasi. Khusu pada hukum perbankan mengenai debitur yang melakukan wanprestasi diatur dalam Pasal 31 Peraturan Bank Indonesia Nomor 14/15/PBI/2012 yang menentukan bahwa debitur wanprestasi apabila : 
a. Terjadi tunggakan pokok dan/atau Bungan dan/atau taguhan lainnya selama 90 (Sembilan puluh) hari walaupun asset produktif belum jatuh tempo.

b. Tidak diterimanya pembayaran pokok dan/atau Bungan da/atau tagihan lainnya pada saat aseet produktif jatuh tempo.

c. Tidak dipenuhinya persyaratan lainnya selain pembayaran pokok dan/atau bunga yang dapat mengakibatkan wanprestasi.

Apabila debitur wanprestasi maka jaminan dari debitur dapat digunakan sebagai pelunasan hutangnya yang harus dibayarkan oleh debitur kepada kreditur. Dari sudut pandang hukum perikatan debitur dianggap telah melakukan wanprestasi apabila :

a. Tidak memenuhi prestasi sama sekali;

b. Memenuhi prestasi tetapi tidak sesuai dengan yang diperjanjikan;

c. Terlambat memenuhi prestasi;

d. Melakukan perbuatan yang tidak diperbolehkan dalam perjanjian.

Sehingga apabila sebelum adanya perjanjian kawin telah ada perbuatan hukum yang berkaitan dengan pihak ketiga seperti perjanjian kreedit maka perubahan atas status hukum terhadap harta bersama tersebut yang ada sebelumnya dalam persatuan bulat harta yang kemudian menjadi terpisah akan menimbulkan permasalahan hukum, sehingga untuk melindungi pihak ketiga atau kreditur dalam pembuatan perjanjian kawin tersebut harus dilakukan dengan cara sebagai berikut :

1. Perjanjian perkawinan harus dibuat di hadapan notaris, Prinsip kehati hatian yang harus dilakukan oleh notaris sebelum membuat perjanjian perkawinan untuk menjaga kepentingan semua pihak agar tidak ada yang dirugikan.

2. Perjanjian kawin dibuat dengan itikad baik dari para pihak.

3. Perjanjian kawin harus dicatatkan pada petugas pencatat perkawinan, agar memberikan perlindungan hukum kapada pihak ketiga atau 
kreditur sehingga terpenuhinya asas publisitas, sebagaimana yang diatur dalam pasal 29 ayat (1) KUHPerdata jo Pasal 3 Undang - Undang Perkawinan.

\section{Kesimpulan}

Perjanjian kawin yang dibuat selama perkawinan berlangsung adalah sebuah perikatan yang dibuat oleh seorang suami dan istri yang telah terikat perkawinan tentang hal - hal yang dikehendakinya sepanjang hal tersebut tidak bertentangan dengan peraturan perundangan undangan yang berlaku serta kaidah - kaidah hukum yang ada di dalam masyarakat, perjanjian kawin yang dibuat selama perkawinan berlangsung harus tetap dilakukan dengan itikad baik dan tidak merugikan pihak ketiga atau kreditur yang sebelumnya telah mengikatkan diri dengan harta suami istri selama terjadi persatuan harta sebelum adanya pemisahan harta sejak ditandatanganinya perjanjian kawin tersebut.

Perihal mengenai perjanjian kawin dapat dibuat setelah perkawinan atau selama perkawinan berlangsung setelah adanya Putusan Mahkamah Konstitusi RI Nomor 69/PUU-XIII/2015, dimana perjanjian kawin yang dibuat selama perkawinan akan mengakibatkan perubahan status terhadap harta yang tadinya merupakan persatuan harta bersama menjadi harta masing-masing pihak secara pribadi. Selain itu juga memberikan dampak pada kreditur yang terikat pada harta tersebut, untuk itu kreditur harus mendapatkan perlindungan hukum baik secara preventif maupun represif. Secara preventif adalah kreditur harus memastikan keabsahan perjanjian kawin tersebut untuk menjaga hak - haknya sebagai pemegang jaminan, sedangkan represif kreditru yang dirugikan dengan adanya perjanjian kawin setelah perkawinan dapat menempuh upaya hukum dengan melakukan pembatalan perjanjian kawin tersebut di Pengadilan Negeri 
dengan melakukan gugatan, kembali lagi untuk mendapatkan pemenuhan hak nya kreditur harus dapat membuktikan bahwa perjanjian tersebut dibuat sebelum adanya perjanjian kawin selama perkawinan, perjanjian kawin tersebut telah merugikan kreditur dan kreditur adalah benar - benar yang berhak mendapatkan pemenuhan kredit yang telah dikeluarkannya kepada debitur.

\section{Daftar Pustaka}

\section{Buku}

Andasasmita. K. (1990). Notaris II Contoh Akta Otentik dan Penjelasannya, Bandung: Ikatan Notaris Indonesia (INI) Daerah Jawa Barat Cetakan Kedua.

Marzuki. P.M. (2009). Penelitian Hukum. Jakarta: Kencana

Prawirohamidjojo. R.S. (1974). Berbagai Masalah Hukum Dalam UU No. 1 Tahun 1974 Tentang Perkawinan. Jakarta : Fakultas Hukum dan Pengetahuan Masyarakat Universitas Trisakti Jakarta

Prawirohamidjojo. S. dan Safiodien. A. (1987). Hukum Orang dan Keluarga. Bandung: Alumni. Cetakan V.

Subekti. R. (1994). Pokok - Pokok Hukum Perdata. Jakarta: Intermasa.

\section{Jurnal}

Andasasmita K. (1990). Notaris II Contoh Akta Otentik dan Penjelasannya, Bandung. Ikatan Notaris Indonesia (INI) Daerah Jawa Barat Cetakan Kedua.

Kusuma. C.H. (2018). Kedudukan Hukum Perjanjian Perkawinan Yang Dibuat Setelah Perkawinan Yang dibuat Setelah Perkawinan Terhadap Pihak Ketiga (Pasca Putusan Mahkamah Konstituso Nomor. 69/PUU-XIII/2015) Jurnal Hukum dan Kenotariatan, Vol. 2, jurnal Volume II- Nomor 1 - Februari 2018. 


\section{Tesis}

Puji Karisma Maharani Kartika, SH. 2011. Akibat hukum Perjanjian Kawin Yang Dibuat Seletah Perkawinan (Studi Kasus : Penetapan Pengadilan Negeri Nomor : 459/Pdt/P/2007/PN.Jkt.TMr). Tesis. Fakultas Hukum Program Magister Kenotariatan Universitas Indonesia. Depok

\section{Internet}

Putusan Nomor 69/PUU-XIII/2015 Mahkamah Konstitusi RI, diambil dari https://www.mkri.id/public/content/persidangan/putusan/69_ PUU-XIII_2015.pdf.

Perjanjian Perkawinan; Dasar Hukum, Fungsi, Materi yang Diatur, dan Waktu Pembuatan, http://kcaselawyer.com. 